\title{
Determination of Paraquat in Several Commercially Available Types of Rice
}

\author{
Thais Lopes Lima1, Maria Aparecida Nicoletti ${ }^{2 *}$, Camila Munhoz ${ }^{3}$, Gabriel Ramos De Abreu ${ }^{4}$, \\ Julia Zaccarelli Magalhães ${ }^{4}$, Esther Lopes Riccis ${ }^{3}$ Paula A. Faria Waziry5, \\ Júlia Nathalia Alves da Costa1, Ana Carolina Nascimento Antônio1, André Rinaldi Fukushima ${ }^{4,6}$
}

\author{
${ }^{1}$ Universidade São Judas Tadeu-R. Taquari, São Paulo/SP, Brazil \\ ${ }^{2}$ Departamento de Farmácia. Faculdade de Ciências Farmacêuticas. Universidade de São Paulo, São Paulo/SP, Brazil \\ ${ }^{3}$ Instituto de Ciências da Saúde, Universidade Presbiteriana Mackenzie, Rua da Consolação, São Paulo/SP, Brazil \\ ${ }^{4}$ Departamento de Patologia, Faculdade de Medicina Veterinária e Zootecnia, Universidade de São Paulo, São Paulo/SP, Brazil \\ ${ }^{5}$ New Southeastern University, Fort Lauderdale, Florida, United States of America Veterans Affairs Medical Center, Miami, \\ Florida, USA \\ ${ }^{6}$ Faculdade São Bento-Largo de São Bento, s/no-Centro, São Paulo-SP, São Paulo/SP, Brazil \\ Email: *nicoletti@usp.br
}

How to cite this paper: Lima, T.L., Nicoletti, M.A., Munhoz, C., De Abreu, G.R., Magalhães, J.Z., Ricci, E.L., Waziry, P.A.F., da Costa, J.N.A., Antônio, A.C.N. and Fukushima, A.R. (2018) Determination of Paraquat in Several Commercially Available Types of Rice. Food and Nutrition Sciences, 9, 1368-1375. https://doi.org/10.4236/fns.2018.912098

Received: October 26, 2018

Accepted: December 21, 2018

Published: December 24, 2018

Copyright (c) 2018 by authors and Scientific Research Publishing Inc. This work is licensed under the Creative Commons Attribution International License (CC BY 4.0).

http://creativecommons.org/licenses/by/4.0/

\section{(c) (i) Open Access}

\begin{abstract}
Introduction: Paraquat (1,1'-dimethyl-4,4'-bipyridine-dichloride) is a herbicide used to combat weeds and improve crop productivity. Its acute toxicity can cause fatal poisoning in humans and animals and several studies have shown a strong correlation between paraquat and Parkinson's disease. Objective: To determine the concentration of paraquat in different types of rice in Brazil. Method: Paraquat quantification is based on a complexation reaction with sodium dithionite, which generates a blueish color compound, whose absorbance was read in a spectrophotometer at the $600 \mathrm{~nm}$ wavelength. Results: Five samples were found to be above the maximum allowed limit, while one sample had a concentration in the upper allowed limit. The method employed did not allow quantification of black rice. Conclusion: There is a need for identification of the type of pesticide used in each examined crop as well as their respective dates of remission in order to improve the safety of agricultural practices.
\end{abstract}

\section{Keywords}

Paraquat, Herbicide, Rice

\section{Introduction}

Weeds can reduce rice harvest and crop quality by competing for light, nutrients 
and space and their seeds can contaminate harvested grains. Some of the most widespread and aggressive weeds are the Echinochloa (rice-grass) species. It has been recorded that infestations of only ten of such weeds per square meter reduced overall yields by $25 \%$ [1].

In order to counteract infesting weeds, it is common to use herbicides that block the germination of seeds or the establishment of weed seedlings [2].

The most used herbicides encompass the following: paraquat, glyphosate, pentachlorophenol, derivatives of phenoxyacetic acid and dinitrophenols [3].

$1,1^{\prime}$-Dimethyl-4,4'-bipyridine-dichloride (paraquat) is a non-selective and extremely toxic herbicide that can cause fatal poisonings in humans and animals [4] [5].

Its chronic exposure may lead to carcinogenic processes, especially in relation to pulmonary diseases [6].

A study that examined the risk of surface water contamination identified the following herbicides as high potential contaminants: Atrazine, azoxystrobin, cypermethrin, chloropyrifos, dicofenol, endosulfan, esfenvarelate, fenitrothion, imidacloprid, lambda cyhalothrin, metolachlor, paraquat, methyl parathion and propiconazole, thiamethoxan and triazophos [7].

Rice is considered the most economically important commodity in many developing countries and it's considered as a basic food source for about 2.4 billion people. It is a crop that shows great adaptability to different soils and climate conditions. Cultivated and consumed on all continents, rice stands out for its production and cultivation area, playing a strategic role, both economically and socially, for the people of the most populous nations of Asia, Africa and Latin America. Compared to other crops, rice stands out second in overall cultivated areas and is surpassed only by wheat. Two main ecosystems are important for consideration of cultivation: the floodplains, which are irrigated by floodwaters; and upland, which are rainfed. These systems encompass all the rice cultivation in the country [8].

As a food with high access to the general population, the National Agency of Sanitary Surveillance (Agência Nacional de Vigilância Sanitária, ANVISA) developed the Program for the Analysis of Agrochemical Waste in food (Programa de Análise de Resíduos de Agrotóxicos, PARA) and 746 rice samples were analyzed. Of these, 715 samples were considered satisfactory, of which 412 did not present detectable pesticide residues among those surveyed and 303 presented residues in concentrations equal to or lower than the maximum residue limit (MRL). In total, 33 different pesticides were detected from 167 analyzed samples [9].

Due to the high rate of rice consumption in Brazil, the objective of this work was to determine quantitatively the amount of paraquat residue in several commercially available types of rice.

\section{Method}

This study was carried out in 2018 at the Nucleus of Pharmaceutical Studies of 
São Judas Tadeu University. The samples were collected from supermarket shelves of large size, which are from brands distributed throughout the national territory.

The method used was adapted from the methodology recommended by $\mathrm{Pe}$ reira and Dantas (1995) [10], which is based on a complexation reaction between paraquat and sodium dithionite, which generates a bluish-colored compound whose absorbance is read in a spectrophotometer at $600 \mathrm{~nm}$ wavelength [10] [11].

To obtain the standard curve, a solution containing $0.021 \mathrm{~g}$ of paraquat was prepared in one liter of nanopore water (solution 1). Serial dilutions were preparing by first transferring $10 \mathrm{~mL}$ of solution 1 to a $500 \mathrm{~mL}$ volumetric flask and completing the volume with nanopore water, which constituted a concentration of $0.4 \mathrm{mg} / \mathrm{L}$ (solution 2). Of the latter, $5 \mathrm{ml}$ was transferred to a final volume of $250 \mathrm{ml}$ to give another solution at $0.008 \mathrm{mg} / \mathrm{L}$ (solution 3 ). The volume of 10 $\mathrm{mL}$ of solutions 2 and 3 and aliquots of $1,2,4,6,8$ and $10 \mathrm{~mL}$ of solution 1 (equivalent to 8 solutions with $0.00008,0.004,0.020 .04,0.08,0.12,0.16$ and $0.2 \mathrm{mg}$ paraquat, respectively) were transferred to $100 \mathrm{ml}$ volumetric flasks. To each of the flasks was added a $10 \mathrm{~mL}$ volume of $1 \%$ sodium dithionite solution in $0.1 \mathrm{~N} \mathrm{NaOH}$, and the volume was quenched with nanopore water. The calibration of the equipment was performed with a sample of paraquat-free rice (organic).

The absorbance values of each of the standard solutions were read in a spectrophotometer at $600 \mathrm{~nm}$ wavelength (UV/VIS mini 1240 - Shimadzu ${ }^{\circledR}$ ). From the absorbance and concentration data, the equation of the line/correlation coefficient was obtained, and from the same, the quantification of paraquat in rice samples was determined.

\section{Results and Discussion}

For the determination of the amount of paraquat in the rice samples, it was necessary to construct a calibration curve that enabled derivation of the linear equation $y=0.803 x+0.0277$. The correlation coefficient was determined to be of 0.9958. The absorbance data obtained with the different concentrations of paraquat are been represented in Figure 1.

The calibration curve allowed determination of paraquat concentrations from the rice samples analyzed. Quantified results are been represented in Table 1.

ANVISA guidelines establishes the following limit values for herbicides applied to rice crops either via post-emergency modality or via desiccant application. Maximum Residue Limit (MRL) of $0.5 \mathrm{mg} / \mathrm{kg}$ with a 7-day safety interval (time interval between the last application of the pesticide and the harvest or commercialization; for cases of post-harvest treatment, this value represents the time interval between the last application and the commercialization); and the acceptable daily intake (ADI) is $0.004 \mathrm{mg} / \mathrm{kg}$ body weight [12].

According to Table 1, of the six samples analyzed, five samples showed values 
Paraquat calibration curve based on sodium dithionite reaction

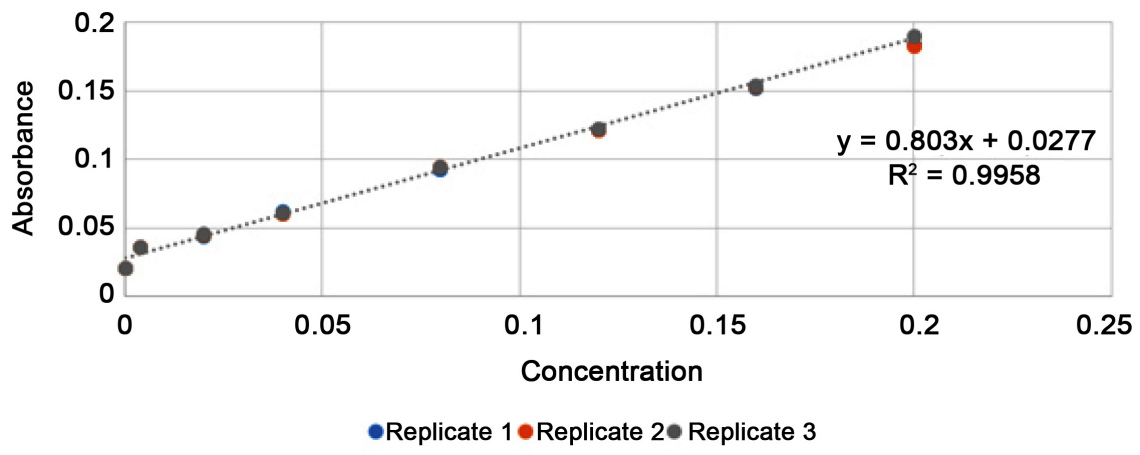

Figure 1. Paraquat calibration curve using the methodology recommended by Pereira and Dantas (1995) [10].

Table 1. Quantification of paraquat found in analyzed rice samples.

\begin{tabular}{|c|c|c|c|c|c|c|}
\hline \multicolumn{7}{|c|}{ Analyzed rice samples } \\
\hline Type of rice & $\begin{array}{c}\text { Replicate } 1 \\
(\mathrm{mg} / \mathrm{kg})\end{array}$ & $\begin{array}{c}\text { Replicate } 2 \\
(\mathrm{mg} / \mathrm{kg})\end{array}$ & $\begin{array}{c}\text { Replicate } 3 \\
(\mathrm{mg} / \mathrm{kg})\end{array}$ & Average & $\begin{array}{l}\text { Standard } \\
\text { Deviation }\end{array}$ & $\begin{array}{c}\text { Coefficient } \\
\text { of Variation } \\
(\%)\end{array}$ \\
\hline Parboiled & 0.20 & 0.20 & 0.21 & 0.20 & 0.00 & 1.28 \\
\hline $\begin{array}{l}\text { Agulhinha } \\
\text { Rice }\end{array}$ & 0.61 & 0.56 & 0.51 & 0.56 & 0.05 & 8.60 \\
\hline Brown Rice & 1.44 & 1.41 & 1.41 & 1.42 & 0.02 & 1.06 \\
\hline $\begin{array}{c}\text { Japanese } \\
\text { Rice }\end{array}$ & 1.02 & 0.71 & 0.96 & 0.90 & 0.16 & 18.26 \\
\hline $\begin{array}{l}\text { Arboreal } \\
\text { Rice }\end{array}$ & 0.75 & 0.64 & 0.66 & 0.68 & 0.06 & 8.61 \\
\hline $\begin{array}{l}7 \text { Grains } \\
\text { Rice }\end{array}$ & 1.32 & 1.36 & 1.36 & 1.35 & 0.03 & 1.98 \\
\hline Wild Rice & $\begin{array}{c}\text { Not } \\
\text { determined }^{*}\end{array}$ & $\begin{array}{c}\text { Not } \\
\text { determined* }\end{array}$ & $\begin{array}{c}\text { Not } \\
\text { determined }^{*}\end{array}$ & $\begin{array}{c}\text { Not } \\
\text { determined }\end{array}$ & $\begin{array}{c}\text { Not } \\
\text { determined }\end{array}$ & $\begin{array}{c}\text { Not } \\
\text { + determined }\end{array}$ \\
\hline
\end{tabular}

above the maximum permitted limit $(0.5 \mathrm{mg} / \mathrm{kg})$ and only one sample showed results that were within the upper limit allowed.

The general consumer population should be guaranteed the right to adequate food, proper health and food quality information. The 1988 article 4 of the Federal Constitution provides for food and nutrition security, covering: "promotion of health, nutrition and food for the population; ensuring the biological, health, nutritional and technological quality of food by encouraging healthy eating practices and lifestyles that respect ethnic and racial diversity" [13].

The Ministry of Health, National Health Surveillance Agency-ANVISA published in the Resolution of Collegiate Board of Directors n. 177 of September 21, 2017 [14] that the prohibition of the active ingredient paraquat in pesticides in the country and in addition to transitory mitigation measures. The Resolution of Collegiate Board of Directors RDC n. 190, of November 30, 2017 [15] amends 
the Resolution of the Collegiate Board of Directors $N^{\circ} 177$, of September 21, 2017 [14], which provides for the prohibition of paraquat's active ingredient in pesticides in the country and on transitional measures to mitigate health risks. The said CDR contains the Annex with the "Risk Knowledge and Responsibility Agreement for Users of Products Based on the Active Ingredient Paraquat" to be attached to the respective Agronomic Revenue. Due to the health risks caused by paraquat, its use will be prohibited in Brazil from September 22, 2020, as established in the Resolution of the Collegiate Board of Directors-RDC 177/2017 [14].

Generally, herbicides are applied directly to the soil, which is why they come into direct contact with organisms of that environment, among them earthworms, which can metabolically act on residues of these compounds. Using earthworms of the Eisenia foetida study, the dissolution of 14C-herbicides was determined (simazine and paraquat) as well as the bioaccumulation of these compounds in their tissues, from soil treatment with the recommended herbicides concentrations. Paraquat studies also included higher than recommended concentrations. Soil and earthworms were analyzed by extraction with solvents and radiometric techniques. Extraction was performed after 30 or 90 days of contact. The earthworms altered the dissipation of simazine, since there was $100 \%$ recovery of the radiocarbon in the absence of earthworms and $90 \%$ in the presence of the animals. In addition, they accumulated residues and/or simazine metabolites in their tissues. A Bioaccumulation Factor (BF) of 1.45 and 1.17 was detected after exposure to treated soil for 30 and 90 days, respectively. On the other hand, the presence of earthworms did not alter the behavior of the herbicide paraquat applied to the soil, but there was a growing bio accumulation of its residues and/or metabolites with increments of treatment dose (FB of 0.5, 3.2 and 5.5, respectively, at the recommended concentrations, 10 and 100 times higher) [16].

The legislation needs to be updated in relation to the consumers' right to know which pesticide was used for the production of foods they are purchasing as well as the grace period (safety interval or grace period, or the time interval between the last application of the pesticide and the harvest or similar respective dates). In this sense, Teixeira (2017) [13] takes an extremely important approach to the right of information in relation to agrochemicals in foods. This author establishes as a presupposition that the relationship between health and healthy eating are directly proportional to the fundamental right to be informed about the quality of commercialized foods.

According to the published report, [9] the Food Agrochemical Waste Analysis Program (PARA) was initiated in 2001 by ANVISA, with the objective of continuously evaluating the levels of pesticide residues in foods of plant origin that reach the consumer's table, serving as an indicator of the occurrence of agrochemical residues in such foods. This program is an initiative of the National Health Surveillance System (SNVS), coordinated by ANVISA in conjunction 
with State and municipal health surveillance agencies and State Public Health laboratories. Since it went into effect, more than 30,000 samples have been analyzed, which included 25 different types of plant-based foods. This initiative has generated:

- Educational and enforcement measures to ensure the use of agrochemicals according to Good Agricultural Practices (GAP);

- Residue data that allows assessment of health risk due to exposure to pesticides in food;

- Support for re-evaluation of pesticides for decision-making on the restriction and banning of pesticides that are harmful to population health.

However, this initiative needs to be intensified at all levels of the production chain for safety of consumption by the population. It is important to note that paraquat is also a concern at the international level. A study published in 2018 surveyed 1971 publications (between 1966 and 2015) that were related to paraquat intoxication in the Scopus ${ }^{\circledR}$ database, evidencing an increase in the production of research in the field of intoxication within the time frame of 2006-2015. The United States published the largest number of studies (338), followed by Japan (228) and China (159). The most prevalent topics covered were "acute paraquat intoxication", "paraquat toxic effects to the lungs" and "paraquat toxicity mechanism". Despite being a survey with numerous publications, there is a current need for further investigation related to the consequences of use it in the production line and relative health effects of the populations that consume treated crops in regards to short, medium and long term of consumption. This purpose justifies investing in a broad interest-free research that involves the use of paraquat [17].

Exposure to paraquat is known as a risk factor for the development of neurodegenerative diseases. It is suspected that paraquat can have harmful effects on astrocyte function and such cells of the central nervous system are implicated in the development of and affected in neurodegenerative diseases and brain injuries. A study of the effects of paraquat on the synaptic functions of astrocytes was developed using human astrocytes (HA1800) that were treated separately with paraquat (PQ) at 200, 400 and $800 \mu \mathrm{mol} / \mathrm{L}$ for 12, 24 and 48 hours, respectively. Results obtained showed that paraquat exerts detrimental effects on synaptic functions of astrocytes, which may be involved in the progressive process of neurodegenerative disorders [18].

Crop growers operate under continuous pressures to meet demands of high yield and maximization of profits. However, it is not possible to disregard paraquat's correlation to neurodegenerative diseases and other health problems.

Availability of safe and high-quality foods still has a long way to go in our country. It is essential to develop programs that encourage analysis of pesticide residues, taking into consideration different types of pesticide usage for food production and processing.

Furthermore, it is imperative for our country to strengthen the National 
Health Surveillance System considering that the Ministry of Health, ANVISA, the National Health Council, the National Council of State Secretaries of Health, the National Council of Secretaries Municipal Health Centers, State Sanitary Surveillance Centers, Federal District and Municipalities, Central Public Health Laboratories, Oswaldo Cruz Foundation and the State, District and Municipal Health Councils, which are participants in health surveillance acts to include a systematic monitoring and control of substances that pose health risks to the population [9].

\section{Conclusions}

There is controversy regarding the release of paraquat as an herbicide, which generates conflicts among regulatory agencies. Paraquat has been implicated in cancer development as well as in neurodegenerative diseases and is therefore a health risk. Alternative non-harmful herbicides should be developed so that paraquat is permanently banned from farming. This argument serves as a base for the implementation of financial incentives towards research and development of alternative health-compliant products. Elimination of paraquat from agricultural practices will most likely impact farmers in regard to crop yields, however, the health of farm workers as well as of the consumer population should be highly prioritized when comparing pesticide usage pros and cons.

Intense implementation of continuous and active product inspection should take place prior to commercialization. Furthermore, there's a need to amend the legislation for inclusion of guidelines/requirements that describe pesticide usage and respective grace periods for safe consumption of treated crops.

\section{Conflicts of Interest}

The authors declare no conflicts of interest regarding the publication of this paper.

\section{References}

[1] Syngenta Crop Protection AG (2018) Centro de Informações sobre paraquat. https://paraquat.com/pt-br/uso/lavouras/arroz

[2] Monquero, P.A., Penha, A.S., Orzari, I. and Hirata, A.C.S. (2011) Seletividade de herbicidas em mudas das espécies nativas Acacia polyphylla, Enterolobium contortisiliquum (Fabaceae), Ceiba speciosa e Luehea divaricata (Malvaceae). Planta daninha, 29, 159-168. https://doi.org/10.1590/S0100-83582011000100018

[3] Mascarenha, T.K.S.F. and Pessoa, Y.S.R.Q. (2013) Aspectos que potencializam a contaminação do trabalhador rural com agrotóxicos: Uma revisão integrativa. Trabalho \& Educação Belo Horizonte, 22, 87-103. https://seer.ufmg.br/index.php/trabedu/article/view/7451/5776

[4] Erickson, T., Brown, K., Widger, H. and Gillespie, M. (1997) A Case of Paraquat Poisoning and Subsequent Fatality Presenting to an Emergency Department. Journal of Emergency Medicine, 15, 649-652. https://doi.org/10.1016/S0736-4679(97)00144-3

[5] Souza, D. and Machado, S.A.S. (2003) Estudo eletroanalítico do herbicida paraquat em soluções aquosas por voltametria de onda quadrada utilizando ultramicroeletrodos. Química Nova, 26. 
https://doi.org/10.1590/S0100-40422003000500004

[6] Costa, M. (2017) Análise de expressão dos genes de reparo da lesão de fita simples do DNA de trabalhadores rurais expostos a agrotóxicos. 118 f. Dissertação [mestrado]. Universidade Federal do Ceará, Faculdade de Medicina, Programa de Pós-Graduação em Ciências Médicas, Ceará.

[7] Canuto, L.G., Gama, A.F., Sá-Barreto, F.M. and Alencar Neto, M.F. (2009) Estimativa do risco potencial de contaminação por pesticidas de águas superficiais e subterrâneas do município de Tianguá-CE, com aplicação do método de goss e índice de gus. In: XVI Congresso Brasileiro De Águas Subterrâneas e XVII Encontro Nacional De Perfuradores De Poços.

https://aguassubterraneas.abas.org/asubterraneas/article/viewFile/23083/15198

[8] AGEITEC (2016) Agência Embrapa de Informação Tecnológica. Árvore do conhecimento. http://www.agencia.cnptia.embrapa.br/gestor/arroz/Abertura.html

[9] Brasil. Ministério da Saúde. Agência Nacional de Vigilância Sanitária (ANVISA). Programa de Análise de Resíduos de Agrotóxicos em Alimentos (PARA). Relatório das análises de amostras monitoradas no período de 2013 a 2015. Brasília, 2016. 246 p. http://portal.anvisa.gov.br/programa-de-analise-de-registro-de-agrotoxicos-para

[10] Pereira, W. and Dantas, R.L. (1995) Qualidade de tubérculos de batatas-semente tratados com Paraquat e o desenvolvimento de uma metodologia simplificada de detecção de resíduo do herbicida. Planta Daninha., 13, 32-38. https://doi.org/10.1590/S0100-83581995000100006

[11] Donagemma, R.A., et al. (2010) Validação de método espectrofotométrico para avaliação e monitoramento de paraquat em solo e água no município de Bom Jardim. Ministério da Agricultura, Pecuária e Abastecimento. Rio de Janeiro: EMBRAPA, 1678-0892.

[12] Brasil. Ministério da Saúde. Agência Nacional de Vigilância Sanitária (ANVISA)-Índice Monográfico-P01-Paraquate. 2018.

http://portal.anvisa.gov.br/documents/111215/117782/P01\%2B\%2BParaquate.pdf/0 ec98b27-1b1f-49de-b788-7bbaa9dfb191

[13] Teixeira, T.M. (2017) Saúde e direito à informação: O problema dos agrotóxicos nos alimentos. Revista De Direito Sanitário, 17, 134-159.

http://www.revistas.usp.br/rdisan/article/view/127782 https://doi.org/10.11606/issn.2316-9044.v17i3p134-159

[14] Brasil. Ministério da Saúde. Agência Nacional de Vigilância Sanitária (ANVISA). Resolução da Diretoria Colegiada n.177, de 21 de setembro de 2017. DOU. 2017; 22 set.

[15] Brasil. Ministério da Saúde. Agência Nacional de Vigilância Sanitária (ANVISA). Resolução da Diretoria Colegiada n.190, de 30 de novembro de 2017. DOU. 2017; 01 dez.

[16] Papini, S. and Andréa, M.M. (2003) Ação de minhocas Eisenia foetida sobre a dissipação dos herbicidas simazina e paraquat aplicados no solo. Red de Revistas Científicas de América Latina y el Caribe, España y Portugal. Seção III-Biologia do Solo, 28, 67-73. https://doi.org/10.1590/S0100-06832004000100007

[17] Zyoud, S.H. (2018) Investigating Global Trends in Paraquat Intoxication Research from 1962 to 2015 Using Bibliometric Analysis. American Journal of Industrial Medicine, 61, 462-470. https://doi.org/10.1002/ajim.22835

[18] Li, Z., Zheng, J. and Zhang, X.F. (2018) Detrimental Effects of Paraquat on Astrocytes-Regulating Synaptic Functions. 1-6.

http://journals.sagepub.com.ez67.periodicos.capes.gov.br/doi/pdf/10.1177/1559325 $\underline{818761681}$ 